\title{
Tanggung Jawab Notaris/PPAT terhadap Akta yang Dibatalkan oleh Pengadilan
}

\author{
Lidya Christina Wardhani \\ Magister Kenotariatan Fakultas Hukum Universitas Islam Indonesia \\ Jl. Cik Di Tiro No. 1 Yogyakarta \\ lidyacw@yahoo.com
}

\begin{abstract}
Notary / PPAT as one public official has an important role in guaranteeing the rule of law, order and legal protection through an authentic deed made by and before him, the authentic act is strong evidence and if there is a dispute in court unless it could be proved guilty, so the deed of Notary / PPAT provide a perfect proof. The problem is how responsibility Notary /PPAT of the certificate canceled by the court? how the legal consequences of the Notary / PPAT due to the cancellation of an authentic act by a court ?. This study is a normative research with the approach of legislation, analytical approach and the approach to the case. The results showed first, Shape responsibility Notary / PPAT of the certificate canceled by the Court related to the case in this study included, civil liability, criminal and administrative. Second, Good cancellations due to civil, criminal, or administrative error by the Notary / PPAT in deed, in general due to the cancellation of the law by the Court of the authentic act is null and void, irrevocable and degraded the strength of evidence.
\end{abstract}

Keywords: Notary, Responsibility, Deed, the Court

\begin{abstract}
Abstrak
Notaris/PPAT sebagai salah satu pejabat umum yang mempunyai peranan penting di dalam menjamin kepastian hukum, ketertiban dan perlindungan hukum melalui akta otentik yang dibuat oleh dan dihadapannya, maka akta otentik merupakan alat bukti yang kuat dan apabila terjadi sengketa di Pengadilan kecuali dapat dibuktikan kesalahannya, sehingga akta Notaris/PPAT memberikan suatu pembuktian yang sempurna. Adapun permasalahannya adalah bagaimana tanggung jawab Notaris/PPAT terhadap akta yang dibatalkan oleh pengadilan? bagaimana akibat hukum terhadap Notaris/PPAT karena dibatalkannya suatu akta otentik oleh Pengadilan?. Peneltian ini merupakan penelitian normatif dengan menggunakan pendekatan perundang-undangan, pendekatan analitis dan pendekatan kasus. Hasil penelitian menunjukkan pertama, Bentuk tanggung jawab Notaris/PPAT terhadap akta yang dibatalkan oleh Pengadilan terkait dengan kasus dalam penelitian ini meliputi, tanggung jawab perdata, pidana dan administratif. Kedua, Baik pembatalan akibat perkara perdata, pidana, maupun kesalahan administratif oleh Notaris/PPAT dalam pembuatan akta, secara umum akibat hukum dibatalkannya akta otentik oleh Pengadilan adalah batal demi hukum, dapat dibatalkan dan terdegradasi kekuatan pembuktiannya.
\end{abstract}

Kata-kata Kunci: Notaris, tanggung jawab, akta, pengadilan 


\section{Pendahuluan}

Untuk menjamin adanya kepastian hukum maka pemerintah menciptakan aturan hukum yang tegas yang mengatur setiap perbuatan warga negaranya yaitu contohnya dengan menciptakan Undang-Undang. Indonesia adalah Negara hukum (rechstaat). Hal tersebut menegaskan bahwa pemerintah menjamin kepastian hukum dalam kehidupan bermasyarakat, berbangsa dan bernegara. Prinsip Negara hukum menjamin kepastian, ketertiban, dan perlindungan hukum yang berintikan kebenaran dan keadilan. Kepastian, ketertiban dan perlindungan hukum menuntut antara lain, bahwa kehidupan masyarakat memerlukan adanya alat bukti yang menentukan dengan jelas hak dan kewajiban seseorang sebagai subjek hukum dalam masyarakat. ${ }^{1}$

Pemerintah kemudian menciptakan profesi hukum untuk membantu mereka yang kurang memahami akan proses dan prosedur hukum yang harus mereka jalani dalam suatu perkara, agar menciptakan kesadaran bagi warga negara dan para pihak akan hukum. Profesi-profesi hukum yang dapat kita temui di sekitar kita meliputi antara lain advokat/pengacara atau Notaris/PPAT.

Notaris adalah pejabat umum yang berwenang membuat akta otentik dan kewenangan lainnya, sebagaimana dimaksud Undang-Undang Nomor 30 Tahun 2004 jo Undang-Undang Nomor 2 Tahun 2014 tentang jabatan notaris. Notaris merupakan jabatan kepercayaan, hal ini mengandung makna bahwa Notaris yang menjalankan tugas jabatan dapat dipercaya dan dalam menjalankan tugas jabatannya, notaris mempunyai kewajiban merahasiakan segala sesuatu mengenai akta yang dibuat dan segala keterangan yang diperolehnya guna pembuatan akta sesuai dengan sumpah atau janji jabatan, kecuali Undang-Undang menentukan lain, seperti yang disebutkan dalam Pasal 16 ayat (1) huruf e tentang Undang-Undang Jabatan Notaris. Ditegaskan pula, bahwa untuk merahasiakan segala sesuatu yang berhubungan dengan akta dan surat-surat lainnya adalah untuk melindungi kepentingan semua pihak yang terkait dengan akta tersebut. ${ }^{2}$ Notaris yang dalam profesinya sesungguhnya merupakan instansi yang dengan akta-aktanya menimbulkan alatalat pembuktian tertulis dan mempunyai sifat otentik. Arti penting dari profesi Notaris ialah bahwa Notaris karena Undang-Undang diberi wewenang menciptakan alat pembuktian yang mutlak dalam pengertian bahwa apa yang tersebut di dalam akta otentik adalah benar. ${ }^{3}$

${ }^{1}$ Abdul Ghofur Anshori, Lembaga Kenotariatan Indonesia: Perspektif Hukum Dan Etika, cetakan pertama, UII Press, Yogyakarta, 2009, hlm. 13

${ }^{2}$ Habib Adji, Merajut Pemikiran Dalam Dunia Notaris \& PPAT, PT. Citra Aditya Bakti, Bandung, 2014, hlm. 12 $7-9$

${ }^{3}$ R. Soegondo Notodisoerjo, Hukum Notariat Di Indonesia Suatu Penjelasan, Rajawali Press, Jakarta, 1982, hlm. 
Sedangkan PPAT didefinisikan sebagai pejabat umum yang berwenang untuk membuat akta otentik mengenai perbuatan hukum tertentu tentang hak atas tanah atau Hak Milik Atas Satuan Rumah Susun. ${ }^{4}$ Seperti halnya Notaris sebagai pejabat umum yang disebut berdasarkan Undang-Undang, pengaturan PPAT sebagai pejabat umum tidak dituangkan ke dalam Undang-Undang, tetapi hanya melalui suatu Peraturan Pemerintah. ${ }^{5}$ Seorang PPAT diberikan kewenangan hukum untuk memberi pelayanan umum kepada masyarakat, dalam pembuatan akta otentik yang merupakan alat bukti yang sempurna berkenaan dengan perbuatan hukum di bidang pertanahan.

Keberadaan Notaris/PPAT ini sangat penting dalam kehidupan masyarakat. Karena Notaris/PPAT memberikan jaminan kepastian hukum pada masyarakat menyangkut pembuatan akta otentik yang dibutuhkan di aktivitas masyarakat baik dalam hal ekonomi, sosial atau politik. Dan untuk membuat akta otentik ini lah dibutuhkan jasa dari Notaris/PPAT, sehingga akta otentik tersebut dapat diterima oleh semua pihak yang bersangkutan serta dapat memiliki kepastian hukum. Akta merupakan suatu tulisan yang dengan sengaja dibuat untuk dapat dijadikan bukti bila terjadi suatu peristiwa dan ditandatangani. ${ }^{6}$

Dari bukti tulisan tersebut, ada bagian yang berharga untuk dilakukan pembuktian yaitu pembuktian tentang akta. Dimana suatu akta merupakan tulisan yang dibuat untuk dijadikan sebagai alat bukti tentang suatu peristiwa dan ditandatangani secukupnya. ${ }^{7}$ Peraturan mengenai akta sendiri juga telah diatur di dalam Pasal 1868 Kitab UndangUndang Hukum Perdata yang berbunyi; "Pengertian akta otentik ialah suatu akta yang didalam bentuk yang ditentukan oleh Undang-Undang, dibuat oleh atau dihadapan pegawaipegawai umum yang berkuasa untuk itu di tempat dimana akta dibuatnya". ${ }^{8}$

Akta Notaris/PPAT merupakan salah satu sumber data bagi pemeliharaan data. Maka wajib dibuat sedemikian rupa sehingga dapat dijadikan dasar yang kuat untuk pendaftaran pemindahan dan pembebanan hak yang bersangkutan. ${ }^{9}$ Akta yang dibuat oleh Notaris/PPAT ini tidak boleh dibuat secara sembarangan baik mengenai bentuk, isi, dan cara pembuatan akta

${ }^{4}$ Urip Santoso, Pejabat Pembuat Akta Tanab (Perspektif Regulasi, Wewenang dan Sifat Akta), Prenadamedia Group, Jakarta, 2016, hlm.61

${ }^{5}$ Husni Thamrin, Pembuatan Akta Pertanahan Oleh Notaris, LaksBang PressIndo, Yogyakarta, 2011, hlm.46

${ }^{6}$ R.Subekti, Hukum Pembuktian, Pradnya Paramita, Jakarta, 2001, hlm. 48 hlm. 157

${ }^{7}$ Darwan Prinst, Strategi Menyusun dan Menangani Gugatan Perdata, CV. Citra Aditya Bakti, Bandung, 2002,

${ }^{8}$ Kitab-Undang-Undang Hukum Perdata, diterjemahkan oleh R.Subekti dan R.Tjitrosudibio cetakan ke 39, Jakarta, Pradnya Paramita, 2008, Pasal 1868

'Boedi Harsono, Hukum Agraria Indonesia Jilid 1 Hukum Tanah Nasional, Jakarta, Djambatan, 2008, hlm. 507 
Notaris/PPAT. Akta Notaris/PPAT merupakan perjanjian para pihak yang mengikat mereka yang membuatnya, maka syarat sahnya suatu perjanjian wajib untuk dipenuhi sesuai dengan Pasal 1320 KUH Perdata yang mengatur tentang syarat sahnya perjanjian.

Notaris/PPAT sebagai salah satu pejabat umum yang mempunyai peranan penting di dalam menjamin kepastian hukum, ketertiban dan perlindungan hukum melalui akta otentik yang dibuat oleh dan dihadapannya, maka akta otentik merupakan alat bukti yang kuat dan apabila terjadi sengketa di Pengadilan kecuali dapat dibuktikan ketidakbenarannya, sehingga akta Notaris/PPAT memberikan suatu pembuktian yang sempurna seperti yang disebutkan di dalam Pasal 1870 KUH Perdata kepada para pihak yang membuatnya. Apabila terjadi suatu sengketa terhadap akta tersebut maka akta tersebut bisa dibatalkan atau batal demi hukum.

Pembatalan akta Notaris/PPAT melalui putusan pengadilan, bukan hanya karena akibat dari kesalahan atau kelalaian Notaris/PPAT saja di dalam membuat akta. Tetapi pembatalan akta Notaris/PPAT juga dapat disebabkan oleh kesalahan atau kelalaian para pihak yang saling mengikatkan diri dalam akta tersebut, sehingga dengan adanya kesalahan atau kelalaian menyebabkan adanya gugatan dari salah satu pihak. Di dalam proses perdata, tidak jarang seorang Notaris/PPAT berada pada kedudukan sebagai turut tergugat yang diberikan sebagai upaya yang dipaksakan, karena di dalam akta notariil khususnya Partij Acte yang kemudian menjadi alat bukti untuk perkara perdata, Notaris/PPAT tidak terlibat bahkan dilarang oleh Undang-Undang terlibat dalam suatu perbuatan hukum sebagaimana yang diterangkan dalam akta notariil yang diresmikannya. Keterlibatan Notaris/PPAT hanya sebatas merumuskan perbuatan hukum para pihak ke dalam aktanya selanjutnya meresmikan akta tersebut. Dipaksakannya mendudukkan Notaris/PPAT sebagai turut tergugat adalah sebagai upaya untuk memaksa Notaris/PPAT membuatkan keterangan seputar aktanya yang sekarang menjadi alat bukti dalam proses peradilan. ${ }^{10}$

Dalam suatu gugatan yang menyatakan bahwa akta Notaris/PPAT tidak sah, maka harus dibuktikan ketidakabsahannya baik dari aspek lahiriah, formal, dan materiil. Jika tidak dapat membuktikannya, maka akta yang bersangkutan tetap sah mengikat bagi para pihak yang berkepentingan atas akta tersebut. Jika akta tersebut dapat dibuktikan di persidangan, maka ada salah satu aspek yang menyebabkan cacatnya akta, sehingga akta tersebut dapat menjadi akta yang terdegradasi atau akta di bawah tangan, bahkan menjadi batal demi hukum. Berdasarkan Pasal 1870 KUH Perdata mengenai kekuatan pembuktian mengikat dan sempurna, suatu akta otentik yang mengikat berarti hakim terikat untuk percaya atas akta

${ }^{10}$ Djoko Sukisno, Pengambilan Fotocopy Minuta Akta dan Pemanggilan Notaris (Mimbar Hukum vol.20 nomor 1), 2008 ,hlm.52 
tersebut selama hal yang menjadi ketidakbenarannya tidak dapat dibuktikan, sedangkan maksud dari sempurna berarti sudah dianggap cukup sebagai alat bukti tanpa ada alat bukti lain.

Hakim secara ex officio pada dasarnya tidak dapat membatalkan akta Notaris/PPAT jika tidak dimintakan pembatalan, karena hakim tidak boleh memutuskan yang tidak diminta. ${ }^{11}$ Jika dimintakan pembatalan oleh pihak yang bersangkutan, pada dasarnya akta otentik tersebut dapat dibatalkan oleh hakim asal ada bukti lawan. Mengenai pembatalan isi akta, seorang Notaris/PPAT hanya bertindak untuk mencatat apa saja yang dikemukakan oleh para penghadap dan tidak wajib untuk menyelidiki kebenaran materiil atas isi akta.

Berdasarkan penjabaran tersebut di atas, dalam penelitian ini akan dibahas mengenai bagaimana dan apa saja tanggung jawab Notaris/PPAT terhadap akta yang dibatalkan oleh Pengadilan, karena beberapa permasalahan yang timbul terkait akta-akta yang dibatalkan, bisa disebabkan kelalaian dan kesalahan dari Notaris/PPAT maupun para pihak yang membuat akta tersebut, Notaris/PPAT sebagai pejabat umum yang diberi kewenangan untuk membuat akta otentik dan tugas jabatannya juga telah diatur di dalam Undang-Undang dan Kode Etik masih melakukan perbuatan yang melawan atau melanggar hukum.

\section{Rumusan Masalah}

Berdasarkan pendahuluan di atas maka rumusan masalah pada penelitian ini adalah Pertama, bagaimana tanggung jawab Notaris/PPAT terhadap akta yang dibatalkan oleh pengadilan? Kedua, bagaimana akibat hukum terhadap Notaris/PPAT karena dibatalkannya suatu akta otentik oleh Pengadilan?

\section{Tujuan Penelitian}

Penelitian ini bertujuan untuk memahami bagaimana tanggung jawab Notaris/PPAT terhadap akta-akta yang dibatalkan oleh pengadilan dan untuk mengetahui akibat hukum bagi Notaris/PPAT terhadap akta-akta yang dibatalkan oleh pengadilan.

\section{Metode Penelitian}

Penelitian ini merupakan penelitian normatif yaitu penelitian yang berfokus pada inventarisasi hukum positif, asas-asas dan doktrin hukum, penemuan hukum dalam perkara konkrit, sistematik hukum, perbandingan hukum dan sejarah hukum. ${ }^{12}$ Pendekatan

11 Sudikno Mertokusumo, Hukum Acara Perdata Indonesia, Liberty, Yogyakarta, 1998, hlm.126

${ }^{12}$ Abdul Kadir Muhammad, Hukum dan Penelitian Hukum, PT. Citra Aditya Bakti, Bandung, 2004, hlm.52 


\section{LEX Renaissance No. 1 VOL. 2 JANUARI 2017: $49-63$}

penelitian yang digunakan dalam penelitian ini adalah : ${ }^{13}$ Pendekatan Undang-Undang (Statute Approach) yaitu pendekatan yang dilakukan untuk meneliti aturan perundangundangan, dan berbagai aturan hukum yang menjadi fokus dari penelitian. Pendekatan Analitis (Analytical Approach) yaitu untuk mengetahui makna yang terkandung oleh istilahistilah yang digunakan dalam peraturan perundang-undangan secara konsepsional sekaligus mengetahui penerapannya dalam praktik dan putusan hukum. Pada dasarnya, pendekatan ini adalah menganalisis pengertian hukum, asas hukum, kaidah hukum, sistem hukum dan berbagai konsep yuridis (perbuatan yang melanggar hukum, delik, dan lain sebagainya) dan pendekatan kasus (Case Approach) yaitu pendekatan yang mempelajari penerapan normanorma atau kaidah hukum yang dilakukan dalam praktik hukum. Pendekatan kasus digunakan mengenai kasus-kasus yang telah mendapat putusan pengadilan, di dalam penelitian normatif kasus-kasus tersebut dapat dipelajari untuk memperoleh suatu gambaran terhadap dampak dimensi penormaan dalam suatu aturan hukum dalam praktik hukum.

Penelitian ini menggunakan data sekunder yang berupa Bahan Hukum Primer, yaitu $^{14}$ yaitu berasal dari bahan-bahan hukum yang terdiri dari Kitab Undang-Undang Hukum Perdata, Undang-Undang Nomor 2 Tahun 2014 tentang Jabatan Notaris, Kitab Undang-Undang Nomor 5 Tahun 1960 tentang Pokok-Pokok Agraria, Peraturan Pemerintah Nomor 37 Tahun 1998 jo Peraturan Pemerintah Nomor 24 Tahun 2016 tentang Tugas dan Wewenang PPAT. Bahan Hukum Sekunder, yaitu bahan hukum yang erat kaitannya dengan data primer dan dapat membantu menganalisis data yang diperoleh dari data primer yaitu dapat berasal dari buku-buku, thesis, atau jurnal yang mengulas tentang permasalahan yang sedang diteliti dan Bahan Hukum Tersier, yaitu data yang memberikan penjelasan tentang data primer dan data sekunder, misalnya dari kamus hukum, kamus bahasa, dan sumbersumber tertulis lainnya. ${ }^{15}$ Data yang diperoleh kemudian dianalisis secara kualitatif dan disajikan dalam bentuk deskriptif.

\section{Hasil Penelitian dan Pembahasan}

\section{Bentuk Tanggung Jawab Notaris/PPAT Terhadap Akta Produknya Yang Dibatalkan Oleh Pengadilan}

Istilah kebatalan dan pembatalan tidak ada yang pasti penerapannya seperti yang dijelaskan oleh Herlien Budiono, yaitu manakala Undang-Undang hendak menyatakan tidak

\footnotetext{
${ }^{13} \mathrm{Ibid}, \mathrm{hlm} .306$

${ }^{14}$ Asri Wijayanti dan Prof. Lilik Sofyan Achmad, Strategi Penulisan Hukum, Lubuk Agung, Bandung, 2011,

15Johnny Ibrahim, Op.Cit, hlm.296
} hlm. 106 
adanya akibat hukum, maka dinyatakan "batal", tetapi adakalanya menggunakan istilah "batal dan tak berhargalah" (Pasal 879 KUH Perdata) atau "tidak mempunyai kekuatan" (Pasal 1335 KUH Perdata). ${ }^{16}$ Jika perjanjian sudah tidak memenuhi syarat objektif, ternyata masih ada yang mengajukan gugatan atau tuntutan atas hal tersebut, maka hakim diwajibkan karena jabatannya menyatakan bahwa tidak pernah ada suatu perjanjian atau perikatan. ${ }^{17}$

Akibat dari suatu kebatalan pada prinsipnya sama antara batal demi hukum, dapat dibatalkan atau non existent yaitu ketiganya mengakibatkan perbuatan hukum tersebut menjadi tidak berlaku atau perbuatan hukum tersebut tidak memiliki akibat hukumnya. atau tiadanya sesuatu yang esensi/pokok dalam perjanjian tersebut. Sehingga, ditinjau dari penyebabnya bahwa batal demi hukum adalah karena tidak dipenuhinya syarat objektif, serta tidak dipenuhinya syarat yang merupakan esensi dalam perjanjian dan karena tidak terpenuhinya bentuk formal sebagaimana diharuskan oleh Undang-Undang/ketentuan yang berlaku yang disebut batal non existent. Perbedaannya yaitu: ${ }^{18}$

a. Batal demi hukum, akibatnya perbuatan hukum yang dilakukan tidak memiliki akibat hukum sejak terjadinya perbuatan hukum tersebut, dalam praktik batal demi hukum didasarkan pada putusan pengadilan yang telah memiliki kekuatan hukum tetap;

b. Dapat dibatalkan, akibatnya perbuatan hukum yang dilakukan tidak memiliki akibat hukum sejak terjadinya pembatalan dan dimana pembatalan atau pengesahan perbuatan hukum tersebut tergantung pada pihak tertentu, yang menyebabkan perbuatan hukum tersebut dapat dibatalkan. Akta yang sanksi nya dapat dibatalkan tetap berlaku dan mengikat selama belum ada putusan pengadilan yang telah memiliki kekuatan hukum tetap yang membatalkan akta tersebut;

c. Non existent, akibatnya perbuatan hukum yang dilakukan tidak ada, yang disebabkan karena tidak dipenuhinya essensialia dari suatu perjanjian atau tidak memenuhi salah satu unsur atau semua unsur dalam suatu perbuatan hukum tertentu. Sanksi non existent secara dogmatis tidak diperlukan putusan pengadilan, namun dalam praktiknya tetap diperlukan putusan pengadilan yang memiliki kekuatan hukum tetap dalam implikasinya sama dengan batal demi hukum.

Istilah pembatalan bersifat aktif, artinya meskipun syarat-syarat perjanjian telah terpenuhi, tapi pra pihak yang terlibat dalam perjanjian tersebut berkehendak agar perjanjian yang dibuat tidak mengikat dirinya lagi dengan alasan tertentu, baik atas dasar kesepakatan atau dengan mengajukan gugatan pembatalan ke pengadilan umum, misalnya para pihak telah

${ }^{16}$ Herlien Budiono, Kumpulan Tulisan Hukum Perdata di Bidang Kenotariatan, PT. Citra Aditya Bakti, Bandung, 2007, hlm.364

${ }^{17}$ R Subekti, Hukum Perjanjian, Intermasa, Jakarta, 2005, hlm.22

18 Mulyoto, Perjanjian (Tehnik, cara membuat, dan bukum perjanjian yang harus dikuasai), Cakrawala Media, Yogyakarta, 2012, hlm. 45 
sepakat untuk membatalkan akta yang pernah dibuatnya, atau diketahui ada aspek formal akta yang tidak dipenuhi, yang tidak diketahui sebelumnya, dan para pihak ingin membatalkannya. ${ }^{19}$

Dalam hukum perjanjian ada akibat hukum tertentu jika syarat subjektif dan syarat objektif tidak dipenuhi. Jika syarat subjektif tidak terpenuhi, maka perjanjian dapat dibatalkan sepanjang ada permintaan oleh orang-orang tertentu atau yang berkepentingan. Syarat subjektif ini senantiasa dibayangi ancaman untuk dibatalkan oleh para pihak yang berkepentingan dari orang tua, wali atau pengampu. Agar ancaman seperti itu tidak terjadi, maka dapat dimintakan penegasan dari mereka yang berkepentingan, bahwa perjanjian tersebut akan tetap berlaku dan mengikat para pihak. Jika syarat objektif tidak dipenuhi, maka perjanjian batal demi hukum, tanpa perlu ada permintaan dari para pihak, dengan demikian perjanjian dianggap tidak pernah ada dan tidak mengikat siapapun.

Perjanjian yang batal mutlak dapat juga terjadi, jika suatu perjanjian yang dibuat tidak dipenuhi, padahal aturan hukum sudah menentukan untuk perbuatan hukum tersebut harus dibuat dengan cara yang sudah ditentukan atau berlawanan dengan kesusilaan atau ketertiban umum, karena perjanjian sudah dianggap tidak ada, maka sudah tidak ada dasar lagi bagi para pihak untuk saling menuntut atau menggugat dengan cara dan bentuk apapun.

Syarat subjektif dicantumkan di awal akta. Unsur syarat subjektif yang pertama adalah kesepakatan, bebas dari para pihak yang berjanji atau tanpa tekanan dan intervensi dari pihak manapun tapi semata-mata keinginan para pihak yang berjanji. Unsur syarat subjektif yang kedua adalah adanya kecakapamn untuk melakukan tindakan dari pihak yang berjanji. Kecakapan melakukan suatu tindakan hukum oleh para pihak dalam akta yang akan menimbulkan akibat hukum tertentu jika tidak memenuhi syarat yang sudah ditentukan. Hal ini berkaitan dengan subjek hukum yang akan bertindak dalam akta tersebut. ${ }^{20}$ Dengan demikian jika dalam awal akta, terutama syarat-syarat para pihak yang menghadap Notaris tidak memenuhi syarat subjektif, maka atas permintaan orang tertentu akta tersebut dapat dibatalkan. Akta Notaris sebagai alat bukti agar mempunyai kekuatan pembuktian yang sempurna, jika seluruh ketentuan prosedur atau tata cara pembuatan akta dipenuhi. Jika ada prosedur yang tidak dipenuhi, dan prosedur yang tidak dipenuhi tersebut dapat dibuktikan, maka akta tersebut dengan proses pengadilan dapat dinyatakan sebagai akta yang mempunyai kekuatan pembuktian sebagai akta di bawah tangan. Jika sudah berkedudukan seperti itu, maka nilai pembuktiannya diserahkan kepada Hakim.

\footnotetext{
${ }^{19}$ Habib Adjie, Kebatalan dan Pembatalan Akta Notaris, PT.Refika Aditama, Bandung, 2013, hlm.67

${ }^{20}$ Ibid
} 
Dalam tataran hukum kenotariatan yang benar mengenai akta Notaris dan Notaris, jika suatu akta Notaris dipermasalahkan oleh para pihak, maka: 1. Para pihak datang kembali ke Notaris untuk membuat akta pembatalan atas akta tersebut, dan dengan demikian akta yang dibatalkan sudah tidak mengikat lagi para pihak, dan para pihak menanggung segala akibat dari pembatalan tersebut. 2. Jika para pihak tidak sepakat akta yang bersangkutan untuk dibatalkan, salah satu pihak dapat menggugat pihak lainnya, dengan gugatan untuk mendegradasikan akta notaris menjadi akta di bawah tangan. Setelah didegradasikan, maka hakim yang memeriksa gugatan dapat memberikan penafsiran tersendiri atas akta Notaris yang sudah didegradasikan, apakah tetap mengikat para pihak atau dibatalkan. Hal ini tergantung pembuktian dan penilaian hakim.

Jika dalam posisi yang lain, yaitu salah satu pihak merasa dirugikan dari akta yang dibuat Notaris, maka pihak yang merasa dirugikan dapat mengajukan gugatan berupa tuntutan ganti rugi kepada Notaris yang bersangkutan, dengan kewajiban penggugat, yaitu dalam gugatan harus dapat dibuktikan bahwa kerugian tersebut merupakan akibat langsung dari akta Notaris. Dalam kedua posisi tersebut, penggugat harus dapat membuktikan apa saja yang dilanggar oleh Notaris, dari aspek lahiriah, aspek formal dan aspek materil atas akta Notaris. $^{21}$

Notaris/PPAT di dalam melaksanakan tugas dan jabatannya sebagai pejabat umum yang berwenang membuat akta otentik dibebani tanggung jawab atas perbuatannya. Tanggung jawab tersebut adalah sebagai kesediaannya untuk melaksanakan kewajibannya yang meliputi kebenaran materiil atas akta yang dibuatnya. Notaris/PPAT bertanggung jawab atas kelalaian dan kesalahan isi akta yang dibuat di hadapannya, melainkan Notaris/PPAT hanya bertanggung jawab terhadap bentuk formal akta otentik seperti yang telah diatur oleh Undang-Undang. Tanggung jawab yang berkaitan dengan kebenaran materiil yaitu antara lain: ${ }^{22}$

1. Tanggung jawab Notaris/PPAT secara perdata terhadap kebenaran materiil terhadap akta yang dibuatnya. Konstruksi yuridis yang digunakan dalam tanggung jawab perdata terhadap kebenaran materiil terhadap akta yang dibuat adalah konstruksi perbuatan melawan hukum.

2. Tanggung jawab Notaris/PPAT secara pidana terhadap kebenaran materiil dalam akta yang dibuatnya. Mengenai ketentuan pidana tidak diatur di dalam Undang-Undang Jabatan Notaris maupun di dalam Peraturan Jabatan Pejabat Pembuat Akta Tanah, namun tanggung jawab Notaris/PPAT secara pidana dikenakan jika Notaris/PPAT tersebut melakukan perbuatan pidana yang melanggar hukum. Undang-Undang Jabatan Notaris

${ }^{21}$ Habib Adjie, Karakter Yuridis Akta Notaris_Indonesia Notary Community.htm

${ }^{22}$ Abdul Ghofur Anshori, Lembaga Kenotariatan Indonesia, UII Press, Yogyakarta, 2009, hlm.16 
dan Peraturan Jabatan Pejabat pembuat Akta Tanah hanya mengatur mengenai sanksi atas pelanggaran yang dilakukan dan sanksi tersebut dapat berupa akta yang dibuat oleh Notaris/PPAT tidak memiliki kekuatan otentik atau hanya memiliki kekuatan sebagai akta dibawah tangan atau malah akta tersebut dibatalkan secara hukum oleh Pengadilan.

\section{Tanggung Jawab Notaris/PPAT Secara Perdata}

Konstruksi yuridis yang digunakan dalam tanggung jawab perdata terhadap kebenaran materiil terhadap akta yang dibuat oleh Notaris adalah konstruksi perbuatan melawan hukum (Pasal 1365 KUH Perdata). Apa yang disebut dengan perbuatan melawan hukum memiliki sifat aktif maupun pasif. Aktif dalam artian melakukan suatu perbuatan yang menimbulkan kerugian pada pihak lain, maka dengan demikian perbuatan melawan hukum merupakan suatu perbuatan yang aktif. Pasif dalam artian tidak melakukan suatu perbuatan tertentu atau suatu keharusan, maka pihak lain dapat menderita suatu kerugian. Unsur dari perbuatan melawan hukum ini meliputi adanya suatu perbuatan melawan hukum, adanya kesalahan dan adanya kerugian yang ditimbulkan.

Sebagaimana perkembangan lembaga perbuatan melawan hukum kontemporer, maka apa yang dimaksud dengan perbuatan melawan hukum adalah perbuatan melawan hukum dalam arti luas. Secara lebih rinci, perbuatan melawan hukum adalah apabila: a. Melanggar hak orang lain; b. Bertentangan dengan kewajiban hukum pelaku; c. Bertentangan dengan kesusilaan; d. Bertentangan dengan kepatutan dalam memperhatikan kepentingan diri dan harta orang lain dalam pergaulan hidup sehari-hari.

Penjelasan Undang-Undang Jabatan Notaris menunjukkan bahwa Notaris hanya sekedar bertanggung jawab terhadap formalitas dari suatu akta otentik dan tidak terhadap materi akta otentik tersebut. Hal ini mewajibkan Notaris untuk bersikap netral dan tidak memihak serta memberikan semacam nasihat hukum bagi klien yang meminta petunjuk hukum pada Notaris yang bersangkutan. Sejalan dengan hal tersebut, maka Notaris dapat dipertanggung jawabkan atas kebenaran materiil suatu akta bila nasihat hukum yang diberikannya ternyata dikemudian hari merupakan suatu yang keliru. Melalui konstruksi penjelasan Undang-Undang Jabatan Notaris tersebut dapat ditarik kesimpulan bahwa Notaris dapat dimintai pertanggung jawaban atas kebenaran materiil suatu akta yang dibuatnya bila ternyata Notaris tersebut tidak memberikan akses mengenai suatu hukum 
tertentu yang berkaitan dengan akta yang dibuatnya sehingga salah satu pihak merasa tertipu atas ketidaktahuannya. ${ }^{23}$

\section{Tanggung Jawab Notaris/PPAT Secara Pidana}

Perbuatan pidana merupakan perbuatan yang dilarang di dalam suatu aturan hukum, dimana larangan tersebut disertai pula dengan sanksi atau ancaman yang berupa sanksi pidana tertentu bagi yang melanggar. Ketentuan pidana tidak diatur di dalam UndangUndang Jabatan Notaris, tetapi secara tanggung jawab pidana, seorang Notaris/PPAT yang melakukan perbuatan pidana dapat dikenakan terhadap Notaris/PPAT tersebut. Di dalam Undang-Undang Jabatan Notaris, hanya mengatur sanksi atas pelanggaran yang dilakukan Notaris/PPAT yang berupa akta yang dibuat tidak memiliki kekuatan otentik atau hanya memiliki kekuatan pembuktian sebagai akta dibawah tangan. Sedangkan terhadap Notaris/PPAT nya, dapat diberikan sanksi berupa teguran sampai pemberhentian dengan tidak hormat.

Perkara pidana yang berkaitan dengan aspek formal akta Notaris, pihak penyidik, penuntut umum, dan hakim akan memasukkan Notaris/PPAT telah melakukan tindakan hukum: a. Membuat surat palsu/yang dipalsukan dan menggunakan surat palsu yang dipalsukan (Pasal 263 ayat (1), (2) KUHP); b. Melakukan pemalsuan (Pasal 264 KUHP); c. Menyuruh mencantumkan keterangan palsu dalam akta otentik (Pasal 266 KUHP); d. Melakukan, menyuruh melakukan, yang turut serta melakukan (Pasal 55 jo Pasal 263 ayat (1) dan 92) atau 264 atau 266 KUHP); e. Membantu membuat surat palsu atau yang dipalsukan dan menggunakan surat palsu atau yang dipalsukan (Pasal 56 ayat (1) dan (2) jo Pasal 263 ayat (1) dan (2) atau 264 atau 266 KUHP). ${ }^{24}$

Jika dikaitkan dengan aspek tindak pidana formal yang dilakukan oleh Notaris/PPAT tersebut, dalam keadaan sadar seseorang juga dapat melakukan perbuatan yang merupakan perbuatan terlarang, maka harus ada unsur kesalahan dari pelaku tindak pidana, yaitu kesengajaan (opzet) dan berhati-hati (culpa). Kesengajaan (opzet) merupakan hal yang terjadi pada sebagian besar tindak pidana. Biasanya diajarkan bahwa kesengajaan itu ada 3 (tiga) macam, yaitu: ${ }^{25}$ a. Kesengajaan yang bersifat suatu tujuan untuk mencapai sesuatu (opzet als oogmerk); b. Kesengajaan yang bukan mengandung suatu tujuan,

${ }^{23}$ Ima Erlie Yuana, Tanggung Jawab Notaris Setelah Berakbir Masa Jabatannya Terhadap Akta Yang Dibuatnya Ditinjau Dari Undang-Undang Nomor 30 Tabun 2004 tentang Jabatan Notaris, Magister Kenotariatan Universitas Diponegoro Semarang, 2010, Thesis

${ }^{24} \mathrm{Ibid}, \mathrm{hlm} .75-76$

${ }^{25}$ Wirjono Prodjodikoro, Asas-Asas Hukum Pidana di Indonesia, Refika Aditama, Bandung, 2011, hlm.65 
melainkan disertai keinsyafan bahwa suatu akibat pasti akan terjadi (opzet bij zekerheidsbewustzijn); c. Kesengajaan tetapi dengan disertai keinsyafan hanya ada kemungkinan (bukan kepastian) bahwa suatu akibat akan terjadi (opzet bij mogelijkheidsbewustzijn). Selain itu, kesengajaan ini juga harus mengenai 3 (tiga) unsur yaitu antara lain: a. Perbuatan yang dilarang; b. Akibat yang menjadi pokok alasan diadakan larangan itu; c. Bahwa perbuatan itu melanggar hukum.

\section{Tanggung Jawab Notaris/PPAT Secara Administratif}

Terdapat korelasi yang sangat kuat antara Undang-Undang Jabatan Notaris, Peraturan Jabatan Pejabat Pembuat Akta Tanah dengan kode etik profesinya. Kode etik profesi mengatur Notaris/PPAT secara internal dan Undang-Undang Jabatan Notaris serta Peraturan Jabatan Pejabat Pembuat Akta Tanah mengatur secara eksternal. Notaris/PPAT di dalam menjalankan tugas jabatannya harus melakukan hal-hal sebagai berikut ${ }^{26}$

a. Notaris/PPAT dituntut melakukan pembuatan akta dengan baik dan benar. Artinya, akta yang dibuat itu memenuhi kehendak umum dan permintaan pihak-pihak yang berkeontingan karena jabatannya;

b. Notaris/PPAT dituntut menghasilkan akta yang bermutu. Artinya, akta yang dibuat itu sesuai dengan aturan hukum dan kehendak pihak-pihak yang berkepentingan dalam arti yang sebenarnya, bukan mengada-ada. Notaris/PPAT harus menjelaskan kepada pihakpihak yang berkepentingan akan kebenaran isi dan prosedur akta yang dibuatnya itu. Serta akta tersebut memiliki dampak yang positif, sehingga siapapun akan mengakui akta tersebut mempunyai kekuatan pembuktian yang sempurna.

Kemudian, perkara yang senantiasa dipermasalahkan yaitu dari aspek formal, terutama mengenai: a. Kepastian hari, tanggal, bulan, tahun, dan pukul menghadap; b. Pihak siapa yang menghadap; c. Tanda tangan yang menghadap; d. Salinan akta tidak sesuai dengan minuta akta; e. Salinan akta ada, tanpa dibuat minuta akta; f. Minuta akta tidak ditandatangani secara lengkap, tapi minuta akta dikeluarkan. Dalam Pasal 85 UndangUndang Jabatan Notaris, diatur juga mengenai sanksi bagi Notaris yang melanggar aspek formal tersebut, yaitu: a. Teguran lisan; b. Teguran tertulis; c. Pemberhentian sementara; d. Pemberhentian dengan hormat; e. Pemberhentian dengan tidak hormat.

\section{Penutup}

Berdasarkan hasil penelitian terkait tanggung jawab Notaris/PPAT terhadap akta yang dibatalkan oleh Pengadilan dapat disimpulkan beberapa hal terkait pokok rumusan 2009, hlm.49

${ }^{26}$ Abdul Ghofur Anshori, Lembaga Kenotariatan Indonesia, Perspektif Hukum dan Etika, UII Press, Yogyakarta, 
masalah dalam penelitian ini, yaitu: Pertama, bentuk tanggung jawab Notaris/PPAT terhadap akta yang dibatalkan oleh Pengadilan terkait dengan kasus dalam penelitian ini meliputi: a) Perdata. Konstruksi pertanggung jawaban secara perdata oleh Notaris adalah Notaris terbukti memenuhi unsur perbuatan melawan hukum dalam Pasal 1365 KUH Perdata dalam membuat aktanya. Karena apabila dalam praktek terbukti memenuhi unsur Perbuatan Melawan Hukum dan merugikan salah satu pihak, maka pihak yang dirugikan dapat mengajukan gugatan ganti rugi terhadap Notaris/PPAT tersebut. b) Pidana. Pertanggung jawaban secara pidana oleh Notaris maupun PPAT adalah Notaris/PPAT juga melakukan tindak pidana sebagai berikut: 1) Membuat surat palsu yang dipalsukan dan menggunakan surat palsu yang dipalsukan (Pasal 263 ayat (1), (2) KUHP; 2) Melakukan Pemalsuan (Pasal 264 KUHP); 3) Menyuruh mencantumkan keterangan palsu dalam akta otentik (Pasal 266 KUHP); 4) Melakukan, menyuruh untuk melakukan, turut serta melakukan (Pasal 55 jo. Pasal 263 ayat (1) dan (92) atau 264 dan 266 KUHP; 5) Membantu membuat surat palsu atau yang dipalsukan dan menggunakan surat palsu atau yang dipalsukan (Pasal 56 ayat 1 dan 2 jo. Pasal 263 ayat (1) dan (2) atau 264 dan 266 KUHP. Atas Pasal-pasal dalam KUHP tersebut, Notaris dapat dikenai pidana penjara minimal 6 (enam) tahun dan penjara maksimal selama 8 (delapan) tahun. c) Administratif. Notaris/PPAT dalam menjalankan kewajibannya telah terbukti membuat akta dengan melanggar pasal-pasal dalam UUJN, Peraturan Pejabat Pembuat Akta Tanah dan kode etik profesinya, maka baik Notaris/PPAT dapat dikenai sanksi administratif sebagaimana yang termuat dalam Pasal 85 UUJN, yakni berupa: 1) Teguran lisan; 2) Teguran tertulis; 3) Pemberhentian sementara; 4) Pemberhentian dengan hormat;5) Pemberhentian dengan tidak hormat.

Kedua, akibat hukum bagi Notaris/PPAT terhadap akta yang dibatalkan oleh Pengadilan adalah sebagai berikut: baik pembatalan akibat perkara perdata, pidana, maupun kesalahan administratif oleh Notaris/PPAT dalam pembuatan akta, secara umum akibat hukum dibatalkannya akta otentik oleh Pengadilan adalah sebagai berikut: 1. Batal demi hukum : akibatnya, perbuatan hukum yang dilakukan tidak memiliki akibat hukum sejak terjadinya perbuatan hukum tersebut dengan suatu putusan pengadilan. 2. Dapat dibatalkan: perbuatan hukum yang dilakukan tidak memiliki akibat hukum sejak terjadinya pembatalan. 3. Terdegradasi kekuatan pembuktiannya (UUJN) : suatu akta otentik memiliki kekuatan pembuktian yang lengkap atau sempurna di dalam persidangan,namun kekuatan tersebut dapat mengalami penurunan mutu/kemunduran/kemerosotan menjadi akta di bawah tangan apabila dalam pembuatannya terjadi pelanggaran terhadap ketentuan persyaratan 


\section{IFx Renaissance No. 1 VOL. 2 JANUARI 2017: $49-63$}

berdasarkan hukum yang berlaku. 4. Bagi Notaris/PPAT yang bersangkutan, dikenai sanksi administratif berupa teguran lisan dan teguran tertulis apabila melakukan pelanggaran ringan. Sedangkan pemberhentian sementara, menurut Pasal 9 UUJN adalah karena dalam proses pailit, berada dibawah pengampuan, melakukan perbuatan tercela atau melakukan pelanggaran terhadap kewajiban dan larangan jabatan, dimana jangka waktu pemberhentian sementara adalah 6 (enam) bulan. Selain sanksi tersebut, Notaris/PPAT yang diberhentikan dengan hormat, menurut Pasal 8 UUJN adalah karena meninggal dunia, telah berumur 65 (enam puluh lima) tahun, permintaan sendiri, tidak mampu secara rohani dan jasmani, dan merangkap jabatan. Sedangkan apabila melakukan perbuatan yang melanwan hukum, maka dapat diberi sanksi berupa diberhentikan dengan tidak hormat apabila oleh pengadilan Notaris dijatuhi pidana penjara lebih dari 5 (lima) tahun, seperti yang telah diatur di dalam Pasal 13 UUJN.

Berdasarkan kesimpulan diatas, maka saran yang akan diberikan penulis adalah sebagai berikut: 1 . Akta otentik memiliki kekuatan pembuktian yang lengkap dan sempurna yang merupakan salah satu produk dari Notaris/PPAT. Maka, untuk menjaga keotentikannya, Notaris/PPAT yang telah diberi tugas dan kewenangan oleh UndangUndang dalam melakukan tugas dan jabatannya seharusnya berpedoman pada aturan-aturan yang telah ada, baik yang telah diatur di dalam Undang-Undang Jabatan Notaris, Peraturan Jabatan Pejabat Pembuat Akta Tanah, kode etik yang telah ditetapkan, serta menjunjung harkat dan martabat sumpah dan organisasi Notaris. 2. Untuk menghindari terjadinya kerugian oleh pihak lain terhadap akta produknya, selain kepada Notaris maupun PPAT, sebaiknya masyarakat lebih berhati-hati dan waspada dalam melakukan perbuatan hukum. Masyarakat harus mengetahui apa yang akan dilakukan tersebut benar atau tidak, dan yang paling penting adalah disertai dengan bukti-bukti dan niat yang baik agar ke depannya, kedudukan dari akta yang dibuatnya menjadi jelas, dan tidak menimbulkan sengketa di kemudian hari sehingga kekuatan pembuktian akta otentik tetap merupakan bukti yang lengkap dan sempurna dalam persidangan.

\section{Daftar Pustaka}

Anshori, Abdul Ghofur, Lembaga Kenotariatan Indonesia: Perspektif Hukum Dan Etika, cetakan pertama, UII Press, Yogyakarta, 2009.

Adji, Habib, Merajut Pemikiran Dalam Dunia Notaris \& PPAT, PT. Citra Aditya Bakti, Bandung, 2014.

, Kebatalan dan Pembatalan Akta Notaris, PT.Refika Aditama, Bandung, 2013. , Karakter Yuridis Akta Notaris_Indonesia Notary Community.htm 
Boediono, Herlien, Kumpulan Tulisan Hukum Perdata di Bidang Kenotariatan, PT. Citra Aditya Bakti, Bandung, 2007.

Harsono, Boedi, Hukum Agraria Indonesia Jilid 1 Hukum Tanah Nasional, Jakarta, Djambatan, 2008.

Ibrahim, Johnny, Teori dan Metodologi Penelitian Normatif, Bayumedia Publising, Malang, 2012

Mertokusumo, Sudikno, Hukum Acara Perdata Indonesia, Liberty, Yogyakarta, 1998.

Muhammad, Abdul Kadir, Hukum dan Penelitian Hukum, PT. Citra Aditya Bakti, Bandung, 2004.

Mulyoto, Perjanjian (Tehnik, cara membuat, dan hukum perjanjian yang harus dikuasai), Cakrawala Media, Yogyakarta, 2012.

Notodisoerjo, R. Soegondo, Hukum Notariat Di Indonesia Suatu Penjelasan, Rajawali Press, Jakarta, 1982

Prinst, Darwan, Strategi Menyusun dan Menangani Gugatan Perdata, CV. Citra Aditya Bakti, Bandung, 2002.

Prodjodikoro, Wirjono, Asas-Asas Hukum Pidana di Indonesia, Refika Aditama, Bandung, 2011.

Santoso, Urip, Pejabat Pembuat Akta Tanah (Perspektif Regulasi, Wewenang dan Sifat Akta), Prenadamedia Group, Jakarta, 2016.

Sukisno, Djoko, Pengambilan Fotocopy Minuta Akta dan Pemanggilan Notaris (Mimbar Hukum vol.20 nomor 1), 2008.

Thamrin, Husni, Pembuatan Akta Pertanahan Oleh Notaris, LaksBang PressIndo, Yogyakarta, 2011.

R.Subekti, Hukum Pembuktian, Pradnya Paramita, Jakarta, 2001.

Wijayanti, Asri dan Prof. Lilik Sofyan Achmad, Strategi Penulisan Hukum, Lubuk Agung, Bandung, 2011.

Yuana, Ima Erlie, Tanggung Jawab Notaris Setelah Berakhir Masa Jabatannya Terhadap Akta Yang Dibuatnya Ditinjau Dari Undang-Undang Nomor 30 Tahun 2004 tentang Jabatan Notaris, Magister Kenotariatan Universitas Diponegoro Semarang, 2010, Thesis

Kitab-Undang-Undang Hukum Perdata, diterjemahkan oleh R.Subekti dan R.Tjitrosudibio cetakan ke 39, Jakarta, Pradnya Paramita, 2008 